\title{
Altered brain concentrations of citalopram and escitalopram in P-glycoprotein deficient mice after acute and chronic treatment
}

Louise Karlsson, Björn Carlsson, Christoph Hiemke, Johan Ahlner, Finn Bengtsson, Ulrich

Schmitt and Fredrik C. Kugelberg

\section{Linköping University Post Print}

\section{Tweet}

N.B.: When citing this work, cite the original article.

Original Publication:

Louise Karlsson, Björn Carlsson, Christoph Hiemke, Johan Ahlner, Finn Bengtsson, Ulrich Schmitt and Fredrik C. Kugelberg, Altered brain concentrations of citalopram and escitalopram in P-glycoprotein deficient mice after acute and chronic treatment, 2013, European Neuropsychopharmacology, (23), 11, 1636-1644.

http://dx.doi.org/10.1016/j.euroneuro.2013.01.003

Copyright: Elsevier

http://www.elsevier.com/

Postprint available at: Linköping University Electronic Press

http://urn.kb.se/resolve?urn=urn:nbn:se:liu:diva-76122 


\section{Altered brain concentrations of citalopram and escitalopram in P-glycoprotein deficient mice after acute and chronic treatment}

Louise Karlsson $^{\mathrm{a}}$, Björn Carlsson ${ }^{\mathrm{a}}$, Christoph Hiemke ${ }^{\mathrm{b}}$, Johan Ahlner ${ }^{\mathrm{a}, \mathrm{c}}$, Finn Bengtsson ${ }^{\mathrm{a}}$,

Ulrich Schmitt $^{\mathrm{b}, 1}$, Fredrik C. Kugelberg ${ }^{\mathrm{a}, \mathrm{c}, *, 1}$

${ }^{a}$ Division of Drug Research, Clinical Pharmacology, Department of Medical and Health Sciences, Linköping University, Linköping, Sweden

${ }^{\mathrm{b}}$ Department of Psychiatry and Psychotherapy, University Medical Center of the Johannes Gutenberg-University of Mainz, Mainz, Germany

${ }^{\mathrm{c}}$ Department of Forensic Genetics and Forensic Toxicology, National Board of Forensic Medicine, Linköping, Sweden

*Corresponding author. Department of Forensic Genetics and Forensic Toxicology, National Board of Forensic Medicine, Artillerigatan 12, SE-587 58 Linköping, Sweden.

Tel.: +4613 252113; fax: +4613252199.

E-mail address: fredrik.kugelberg@liu.se (F.C. Kugelberg)

${ }^{1}$ These authors share the last authorship.

Short title:

Altered brain concentrations of citalopram and escitalopram in P-gp deficient mice 


\begin{abstract}
According to both in vitro and in vivo data $\mathrm{P}$-glycoprotein $(\mathrm{P}-\mathrm{gp})$ may restrict the uptake of several antidepressants into the brain, thus contributing to the poor success rate of current antidepressant therapies. The therapeutic activity of citalopram resides in the S-enantiomer, whereas the R-enantiomer is practically devoid of serotonin reuptake potency. To date, no in vivo data are available that address whether the enantiomers of citalopram and its metabolites are substrates of P-gp. P-gp knockout $(a b c b l a b(-/-))$ and wild-type $(a b c b l a b(+/+))$ mice underwent acute (single-dose) and chronic (two daily doses for 10 days) treatment with citalopram (10 mg/kg) or escitalopram $(5 \mathrm{mg} / \mathrm{kg})$. Serum and brain samples were collected 1$6 \mathrm{~h}$ after the first or last i.p. injection for subsequent drug analysis by an enantioselective HPLC method. In brain, 3-fold higher concentrations of S- and R-citalopram, and its metabolites, were found in $a b c b l a b(-/-)$ mice than in $a b c b l a b(+/+)$ mice after both acute and chronic citalopram treatments. After escitalopram treatment, the S-citalopram brain concentration was 3-5 times higher in the knockout mice than in controls. The results provide novel evidence that the enantiomers of citalopram are substrates of P-gp. Possible clinical and toxicological implications of this finding need to be further elucidated.
\end{abstract}

Keywords: abcb1ab; citalopram; enantiomers; escitalopram; knockout mice; P-glycoprotein 


\section{Introduction}

The blood-brain barrier (BBB) contains various membrane transporters and one of the most important is $\mathrm{P}$-glycoprotein (P-gp) which regulates the efflux of several central nervous system (CNS) active drugs (Loscher and Potschka, 2005). P-gp can limit the penetration into, and retention within, the brain and thus modulate the effectiveness and CNS toxicity of numerous compounds (Ebinger and Uhr, 2006). High levels of P-gp have been found in the endothelial cells that line small blood capillaries and form the BBB (Cordon-Cardo et al., 1989). P-gp is not only expressed in the BBB, it is expressed for example in the kidneys, liver and the intestine (Thiebaut et al., 1987, 1989). P-gp is encoded by the $A B C B 1$ gene (or $M D R 1)$ in humans and by $a b c b l a(m d r l a$ or $m d r 3)$ and $a b c b 1 b(m d r 1 b$ or $m d r 1)$ in mice (Devault and Gros, 1990). The two mouse genes are supposed to exhibit similar characteristics as the human isoform. Accordingly, the $a b c b l a b$ knockout mouse model has been a valuable tool to identify drugs that are P-gp substrates (Doran et al., 2005; Karlsson et al., 2011; Karlsson et al., 2010; Kirschbaum et al., 2008; Uhr and Grauer, 2003; Uhr et al., 2003; Uhr et al., 2000; Wang et al., 2004).

The existence of two pharmacophores on P-gp increases the possibilities for multiple chemical structure recognition (Garrigues et al., 2002). This is one reason that the P-gp substrate specificity of drugs should be considered on individual merit. According to both in vitro and in vivo data P-gp may restrict the uptake of several antidepressants into the brain, thus contributing to the poor success rate of current antidepressant therapies (Ejsing et al., 2007; Linnet and Ejsing, 2008; O'Brien et al., 2012). While there is evidence that venlafaxine and paroxetine are substrates of P-gp (Karlsson et al., 2010; Uhr et al., 2003), the results are contradictory for citalopram (Rochat et al., 1999; Uhr and Grauer, 2003). Uhr and Grauer (2003) showed that the brain concentrations of racemic citalopram in wild-type mice were 
lower than the brain concentrations in P-gp knockout mice, suggesting that citalopram is actively exported out of the brain by P-gp. However, no in vivo data are available that address whether the enantiomers of citalopram and its metabolites are substrates of P-gp.

Citalopram is a racemic mixture of the (S)-(+)- and (R)-(-)-enantiomers. The SSRI activity of citalopram resides in S-citalopram, whereas R-citalopram is practically devoid of serotonin reuptake inhibitory potency (Burke et al., 2002; Hyttel et al., 1992; Lepola et al., 2004; Montgomery et al., 2001; Owens et al., 2001; Wade et al., 2002). Due to this fact, Scitalopram has been developed as a single enantiomer drug (escitalopram). In addition, using a variety of behavioral tests, it has been shown that escitalopram displays a more rapid and efficacious effect than citalopram, and that R-citalopram counteracts these effects in vivo and in vitro (Mork et al., 2003; Sanchez et al., 2003a; Sanchez et al., 2003c; Sanchez and Kreilgaard, 2004). Accordingly, it is of clinical as well as toxicological relevance to examine the role of P-gp on possible differences in the brain disposition of the S- and R-enantiomers of citalopram and its metabolites. Therefore, in the present study, enantiomeric drug and metabolite concentrations were measured in serum and brain samples from P-gp knockout and wild-type mice after acute and chronic treatment with citalopram and escitalopram.

\section{Experimental procedures}

\subsection{Drugs and chemicals}

For the citalopram experiments, racemic citalopram- $\mathrm{HBr}$ (kindly provided by $\mathrm{H}$. Lundbeck A/S, Copenhagen-Valby, Denmark) was dissolved in $0.9 \% \mathrm{NaCl}$ and administered intraperitoneally (i.p.). For the escitalopram experiments, an infusion solution consisting of escitalopram (Lundbeck A/S, Copenhagen-Valby, Denmark) was used for the i.p. injections. All other chemicals were of the purest grade commercially available. 


\subsection{Animals}

Male $a b c b l a b(-/-)$ mice (mean weight, $32 \mathrm{~g}$ ) on a FVB/N background (Taconic, Germantown, NY) and male FVB/N wild-type mice $(a b c b l a b(+/+))$ (mean weight, $29 \mathrm{~g}$ ) were housed in groups of 2-5 in cages with sawdust bedding under normal indoor temperature $\left(22^{\circ} \mathrm{C}\right)$ and humidity $(60 \%)$, and maintained on 12-hour light-dark cycle, with food and water ad libitum. All experiments were performed in accordance with the guidelines and were approved by local authorities.

\subsection{Experimental design}

\subsubsection{Acute experiments}

Citalopram and escitalopram were administered to $a b c b l a b(-/-)$ knockout ( $\mathrm{n}=5$ per time point and drug) and $a b c b l a b(+/+)$ wild-type (n=5 per time point and drug) mice by a single i.p. injection during a brief anesthesia with isoflurane (Forene ${ }^{\circledR}$, Abbott $\mathrm{GmbH} \& \mathrm{Co} . \mathrm{KG}$, Wiesbaden, Germany). The doses used were $10 \mathrm{mg} / \mathrm{kg}$ citalopram or $5 \mathrm{mg} / \mathrm{kg}$ escitalopram and the total volume injected was $1 \mathrm{ml}$. The intermediate dose of $10 \mathrm{mg} / \mathrm{kg}$ was chosen according to the literature (Bourin et al., 1998; Crowley et al., 2005; Cryan et al., 2004). At 1, 3 and 6 hours following drug administration, the mice were decapitated under anesthesia with isoflurane. Trunk blood was collected in tubes and thereafter the brain was dissected. The blood samples were left at room temperature to allow clotting and thereafter centrifuged (3000g for $10 \mathrm{~min}$ ). The brains were weighed and homogenized in $2 \mathrm{ml}$ Milli-Q water (Millipore AB, Stockholm, Sweden) by sonification (Sonics Vibra-Cell VC 130; Chemical Instruments AB, Sweden) and centrifuged at $2000 \mathrm{~g}$ for $15 \mathrm{~min}$. All samples were frozen at $70^{\circ} \mathrm{C}$ until further analysis. 


\subsubsection{Chronic experiments}

Abcblab (-/-) (n=5) and $a b c b l a b(+/+)$ mice (n=5 per drug) were injected i.p. with $10 \mathrm{mg} / \mathrm{kg}$ citalopram or $5 \mathrm{mg} / \mathrm{kg}$ escitalopram twice daily (9:00 a.m. and 7:00 p.m.) for 10 days. Two of the knockout mice died for unknown reasons during citalopram treatment (i.e. $n=3$ in this group), but otherwise, the mice tolerated the treatment well. One hour after the last injection, the animals were decapitated under isoflurane anesthesia. The samples were collected and processed in the same way as the acute samples (see section 2.3.1 above).

\subsection{Drug concentration determination}

The concentrations of the S- and R-enantiomers of citalopram, demethylcitalopram (dmcitalopram), and didemethylcitalopram (ddm-citalopram) in serum (nmol/l) and brain homogenate supernatant $(\mathrm{pmol} / \mathrm{g} \approx \mathrm{nmol} / \mathrm{l})$ were determined by using HPLC with fluorescence detection as described previously (Rochat et al., 1995) with some modifications (Carlsson et al., 2001; Kugelberg et al., 2001). The enantiomers of citalopram, dm-citalopram, ddm-citalopram and internal standard (a chlorinated version of citalopram, Lu 10-202-O; H. Lundbeck A/S) were extracted with solid-phase extraction on Isolute C2 columns (International Sorbent Technology Ltd). The limits of detection for the enantiomers of citalopram and its metabolites were $2 \mathrm{nmol} / \mathrm{l}$, respectively. Standards were prepared with the following concentrations $15-616 \mathrm{nmol} / \mathrm{l}(5-200 \mathrm{ng} / \mathrm{ml})$ for citalopram, 8-322 nmol/l (2.5-100 $\mathrm{ng} / \mathrm{ml})$ for dm-citalopram and 1.7-67 nmol/l (0.5-20 ng/ml) for ddm-citalopram. The absolute recoveries from spiked drug-free plasma were between 87 and 110\% (Carlsson et al., 2001). The brain tissue extraction recoveries for citalopram and metabolites were found to be around 40\% (Wikell et al., 1999). 


\subsection{Statistics}

Data are presented as means \pm SEM. Student's t-test for unpaired observations was used to compare differences between $a b c b 1 a b(-/-)$ and $a b c b l a b(+/+)$ mice. A probability less than $5 \%(\mathrm{p}<0.05)$ was considered statistically significant. All statistical analyses were performed using StatView ${ }^{\circledR}$ for Windows Version 5.0 (SAS ${ }^{\circledR}$ Institute, Cary, NC; USA).

\section{Results}

\subsection{Citalopram treatment}

The concentrations of the S- and R-enantiomers of citalopram in serum and brain are displayed in Table 1. The S-enantiomer concentrations of the metabolites are shown in Table 2. In both wild-type and knockout animals, the concentrations of citalopram in brain were higher compared to drug concentrations in serum after injection of citalopram at all time points. The brain concentration of the S-enantiomer of citalopram was 2.8-3.4 times higher in the knockout mice than in controls (Fig. 1C: acute $1 \mathrm{~h}, \mathrm{p}<0.001$; acute $3 \mathrm{~h}, \mathrm{p}<0.001$; chronic 1 $\mathrm{h}, \mathrm{p}<0.01)$. For the metabolites, the brain concentrations of the S-enantiomer of dmcitalopram and ddm-citalopram were 2.7-13 and 3.5-17 (except for S-ddm-citalopram at $1 \mathrm{~h}$ ) times higher in the knockout mice than in controls, respectively (Table 2). The mean ratio of brain to serum S-enantiomer concentration of citalopram and dm-citalopram was significantly higher in the knockout mice than in the wild-type mice (Fig. 2A and C). The enantiomeric S/R concentration ratio of citalopram in serum was significantly higher in wild-type mice than in knockout mice after acute $(1 \mathrm{~h})$ treatment (Fig. 3A), but no difference was observed after chronic treatment (Fig. 3B).

\subsection{Escitalopram treatment}


The serum and brain concentrations of escitalopram and metabolites are displayed in Table 1 and Table 2, respectively. The S-citalopram brain concentration was 3.2-4.6 fold higher in the knockout mice than in controls (Fig 1D: acute $1 \mathrm{~h} p<0.01$; acute $3 \mathrm{~h} \mathrm{p}<0.001$; chronic $1 \mathrm{~h}$, $\mathrm{p}<0.001)$. There were no differences in serum concentrations between the knockout and wildtype mice. For the metabolites dm-citalopram and ddm-citalopram, the brain concentration of the S-enantiomer was 3.2-6.4 and 2.6-10 times higher in the knockout mice than in controls (Table 2). The mean ratio of brain to serum S-enantiomer concentration of citalopram and dm-citalopram was significantly higher in knockout mice than in control mice (Fig. 2B and D).

\subsection{Comparison of citalopram and escitalopram treatment}

The serum and brain S-citalopram concentrations after citalopram and escitalopram treatment are displayed in Fig. 1 and Table 1. When comparing the two treatment regimens in wild-type mice, the serum concentrations of citalopram and escitalopram were in the same range (632$740 \mathrm{nmol} / \mathrm{l})$ for the acute $(1 \mathrm{~h})$ and chronic groups (Fig. 1A-B). However, at the $3 \mathrm{~h}$ time point a difference between the treatments were found with 2 fold higher S-citalopram concentrations in serum after citalopram treatment compared to escitalopram treatment (121 vs. $59.3 \mathrm{nmol} / \mathrm{l}$ ). Both treatments resulted in brain S-citalopram concentrations in the same range for all three time points (Fig. 1C-D).

When comparing the S-enantiomer concentrations for the metabolites dm-citalopram and ddm-citalopram in wild-type mice, higher serum concentrations were found in animals treated with escitalopram ( 2 and 4.6 folds) compared to animals treated with citalopram (Table 2). Comparing S-enantiomer metabolite/parent drug (M/P) ratios for dm-citalopram/citalopram, the ratios were 1.2, 5.6 and 0.7 in animals treated with citalopram and 2.9, 6.9 and 1.5 in 
animals treated with escitalopram ( $1 \mathrm{~h}, 3 \mathrm{~h}$ and 10 days, respectively). Considering the Renantiomer in animals treated with citalopram, total $(\mathrm{S}+\mathrm{R})$ concentration $\mathrm{M} / \mathrm{P}$ ratios for $\mathrm{dm}-$ citalopram/citalopram were 1.1, 4.2 and 0.6. In brain, M/P ratios for dmcitalopram/citalopram were $0.08,1.2$ and 0.05 in animals treated with citalopram and $0.3,3.9$ and 0.1 in animals treated with escitalopram ( $1 \mathrm{~h}, 3 \mathrm{~h}$ and 10 days, respectively).When comparing serum and brain concentrations of citalopram and metabolites in $a b c b l a b(-/-)$, similar results as for the wild-type mice are seen with higher concentrations of metabolites in mice treated with escitalopram (serum M/P ratios of $0.7,2.8$ and 0.7 after citalopram treatment and 3.0, 9.0 and 1.3 in escitalopram treated mice, $1 \mathrm{~h}, 3 \mathrm{~h}$ and 10 days, respectively).

\section{Discussion}

The results of the present study provide novel evidence that both the S- and R-enantiomers of citalopram are substrates of P-gp. In addition, escitalopram has to our knowledge not previously been tested in this mice model. We report 3 times higher brain concentrations of Sand R-citalopram, and its metabolites, in $a b c b l a b(-/-)$ knockout mice than in $a b c b l a b(+/+)$ wild-type mice after both acute and chronic citalopram treatment. After escitalopram treatment, the S-citalopram brain concentration was 3-5 times higher in the knockout mice than in controls.

For citalopram, our results are in line with the results reported by Uhr and Grauer (2003) using the same animal model. They reported a brain $a b c b l a b(-/-)$ to wild-type concentration ratio of 3.0 one hour after s.c. treatment (present study 3.1). Our chronic results are also in line with a similar study by Uhr et al. (2008) with a brain $a b c b l a b(-/-)$ to wild-type concentration ratio of 2.8 (present study) compared to 3.0. In a recently published study in 
which the single knockout mice ( $m d r l a$ deficient mice) were used for chronic citalopram treatment, a brain abcbla (-/-) to wild-type concentration ratio of 1.9 was observed (Bundgaard et al., 2011). The absolute brain concentrations differed due to differences in administration regimes; i.e. daily injections and osmotic pumps, respectively, and duration of treatment. The present study included a longer time span than other investigators (up to $6 \mathrm{~h}$ ), measurements of the enantiomeric drug and metabolite concentrations, and also escitalopram treatment. In the present study, the ratio of citalopram concentration in brain between $a b c b l a b(-/-)$ mice and wild-type mice was 3.1 (1 h, acute). We showed recently for the antidepressant venlafaxine that the ratio of concentration in brain between $a b c b l a b(-/-)$ mice and wild-type mice ranges between 2.0 and 3.7 for the mother compound (Karlsson et al., 2011; Karlsson et al., 2010). These ratios might not be considered very high compared with some substances with higher affinity for P-gp e.g. digoxin (ratio 19) (Mayer et al., 1997). However, according to other investigators (Doran et al., 2005), an increase by $200 \%$ or more in brain concentration of antidepressants is considered to be of clinical relevance in patients undergoing therapy.

The acute and chronic treatment regimens resulted in similar pharmacokinetic profiles for both citalopram (wild-type brain/serum ratio 2.0 and 1.6, acute vs. chronic; $p=0.1$ ) as well as escitalopram (wild-type brain/serum ratio 1.7 and 1.2, acute vs. chronic; $\mathrm{p}=0.07$ ) indicating that the chronic treatment has no, or very little, effect on the expression levels of P-gp, at least up to 10 days of drug administration. This is in contrast to other substrates of P-gp such as dexamethasone and ritonavir (Gutmann et al., 2006; Narang et al., 2008; Perloff et al., 2004). However, venlafaxine has been reported to induce the expression of P-gp (Doran et al., 2005; Ehret et al., 2007) an effect not seen in our previous acute and chronic venlafaxine studies in the wild-type mouse (Karlsson et al., 2011; Karlsson et al., 2010). In another recently 
published study, venlafaxine was found to induce the expression of P-gp but no effect on induction was seen for desvenlafaxine (i.e. O-desmethylvenlafaxine) (Bachmeier et al., 2011). It should be mentioned that we have not measured the expression of P-gp and that there might be an induction not seen in our results. In the present study, we have focused on brain and serum. This might be a limitation but on the other hand, Uhr and co-workers have shown in previous studies that administration of antidepressants (amitriptyline and citalopram) did not result in any significant differences in tissue drug levels besides the brain (Uhr and Grauer, 2003; Uhr et al., 2007; Uhr et al., 2000). The results from these studies indicate that although transport in other tissues than the brain is also eliminated by the P-gp knockout its overall impact seems to be of limited relevance.

P-gp might have different affinity for the enantiomers of citalopram. Interestingly, using a variety of in vivo and in vitro models, it has been shown that R-citalopram counteracts the serotonin enhancing properties of S-citalopram (Mansari et al., 2007; Mnie-Filali et al., 2007; Mork et al., 2003; Sanchez et al., 2004; Sanchez et al., 2003b). This finding of an unfavorable effect of R-citalopram emphasizes the relevance of the importance of enantioselective drug analysis, especially in depressive patients not responding to citalopram treatment. In the present study, we investigated the disposition of the S- and R-enantiomers of citalopram and metabolites to explore a potential stereoselective P-gp mediated transport. However, such evidence could not be found. To further elucidate this matter it would be interesting to investigate the pharmacokinetics of the pure R-enantiomer of citalopram in P-gp deficient mice. The mean serum $S / R$ ratios of citalopram after acute and chronic treatment were 2.7 and 2.3 in knockout mice and 3.8 and 2.5 in wild-type mice. The differences in serum S/R ratios seen after acute treatment cannot be completely explained by accumulation in brain. The total loss of P-gp might change the volume of distribution which can influence the drug elimination 
(Endres et al., 2006). These enantiomeric ratios are much higher compared to corresponding ratios in humans and rats $(\mathrm{S} / \mathrm{R}$ ratios of 0.59 in patients and around 0.9 in rats given $10 \mathrm{mg} / \mathrm{kg}$ citalopram) indicating possible species differences (Carlsson et al., 2001; Kugelberg et al., 2001, 2003). When comparing S/R ratios, there can be a stereoselective metabolism in mice not seen in humans or the opposite situation. In humans, citalopram is metabolized primarily by CYP2C19 and to a lesser extent by CYP2D6 and CYP3A4 (Brøsen and Naranjo, 2001; Fudio et al., 2010; Yin et al., 2006). Studies have shown a stereoselective metabolism where the enzymes favor a more rapid demethylation of the S-enantiomer over the R-enantiomer. Further metabolism of dm-citalopram into ddm-citalopram is also shown to be stereoselective but with a more rapid demethylation of the R-enantiomer over the S-enantiomer (Olesen and Linnet, 1999). Citalopram and the two metabolites can also be stereoselectively metabolized into propionic acid by monoamine oxidase B (MAO B) where the S-enantiomer is favored over the R-enantiomer (Kosel et al., 2001; Rochat et al., 1998). The metabolism of citalopram in mice has to our knowledge not been studied in the same detailed manner as for rats. However, a stereoselective drug metabolism in mice is the most likely explanation for the higher M/P ratios observed after escitalopram treatment compared with citalopram treatment. The serum (S+R) dm-citalopram/citalopram ratios in humans are 0.31-0.60 (Reis et al., 2003) which can be compared to the present serum ratios of 0.63-4.2 in wild-type mice after citalopram treatment. Other factors to consider when comparing results from different studies are the administration routes, the dose given and the time of sampling in relation to when the drug was given.

Drug levels in the brain could affect therapy response and clinical outcome. Consequences of enantioselectivity in the activity of P-gp should not be neglected (Choong et al., 2010). It has been reported that several factors can influence the level of P-gp expression in man. Some 
single nucleotide polymorphisms (SNPs) in the $A B C B 1$ gene have been studied (Kim et al., 2001), that influences P-gp expression and result in functional differences in absorption and disposition of drugs (Hoffmeyer et al., 2000). Furthermore, drugs are known to induce or inhibit P-gp function in vivo, e.g. dexamethasone, rifampicin, verapamil, cyclosporine A, HIV protease inhibitors, as well as psychoactive drugs.

In summary, it is concluded that P-gp actively transports both the S- and R-enantiomers of citalopram and its two demethylated metabolites. We found no evidence for a stereoselective P-gp mediated transport. Further studies are encouraged to explore possible clinical and toxicological consequences of this finding.

\section{References}

Bachmeier, C.J., Beaulieu-Abdelahad, D., Ganey, N.J., Mullan, M.J., Levin, G.M., 2011. Induction of drug efflux protein expression by venlafaxine but not desvenlafaxine. Biopharm. Drug Dispos. 32, 233-244.

Bourin, M., Colombel, M. C., Redrobe, J. P., Nizard, J., Hascoet, M., Baker, G. B., 1998. Evaluation of efficacies of different classes of antidepressants in the forced swimming test in mice at different ages. Prog. Neuropsychopharmacol. Biol. Psychiatry. 22, 343-351.

Brøsen, K., Naranjo, C.A., 2001. Review of pharmacokinetic and pharmacodynamic interaction studies with citalopram. Eur. Neuropsychopharmacol. 11, 275-283.

Bundgaard, C., Jes Nyberg Jensen, C., Garmer, M., 2012. Species Comparison of In Vivo Pglycoprotein Mediated Brain Efflux Using mdr1a Deficient Rats and Mice. Drug Metab. Dispos. 40, 461-466.

Burke, W.J., Gergel, I., Bose, A., 2002. Fixed-dose trial of the single isomer SSRI escitalopram in depressed outpatients. J. Clin. Psychiatry. 63, 331-336.

Carlsson, B., Olsson, G., Reis, M., Walinder, J., Nordin, C., Lundmark, J., Scordo, M.G., Dahl, M.L., Bengtsson, F., Ahlner, J., 2001. Enantioselective analysis of citalopram and metabolites in adolescents. Ther. Drug Monit. 23, 658-664.

Choong, E., Dobrinas, M., Carrupt, P.A., Eap, C.B., 2010. The permeability P-glycoprotein: a focus on enantioselectivity and brain distribution. Expert Opin. Drug Metab. Toxicol. 6, 953965. 
Cordon-Cardo, C., O'Brien, J. P., Casals, D., Rittman-Grauer, L., Biedler, J. L., Melamed, M. R., Bertino, J. R., 1989. Multidrug-resistance gene (P-glycoprotein) is expressed by endothelial cells at blood-brain barrier sites. Proc. Natl. Acad. Sci. U S A. 86, 695-698.

Crowley, J. J., Blendy, J. A., Lucki, I., 2005. Strain-dependent antidepressant-like effects of citalopram in the mouse tail suspension test. Psychopharmacology (Berl). 183, 257-264.

Cryan, J. F., O'Leary, O. F., Jin, S. H., Friedland, J. C., Ouyang, M., Hirsch, B. R., Page, M. E., Dalvi, A., Thomas, S. A., Lucki, I., 2004. Norepinephrine-deficient mice lack responses to antidepressant drugs, including selective serotonin reuptake inhibitors. Proc. Natl. Acad. Sci. U S A. 101, 8186-8191.

Devault, A., Gros, P., 1990. Two members of the mouse mdr gene family confer multidrug resistance with overlapping but distinct drug specificities. Mol. Cell Biol. 10, 1652-1663.

Doran, A., Obach, R.S., Smith, B.J., Hosea, N.A., Becker, S., Callegari, E., Chen, C., Chen, X., Choo, E., Cianfrogna, J., Cox, L.M., Gibbs, J.P., Gibbs, M.A., Hatch, H., Hop, C.E., Kasman, I.N., Laperle, J., Liu, J., Liu, X., Logman, M., Maclin, D., Nedza, F.M., Nelson, F., Olson, E., Rahematpura, S., Raunig, D., Rogers, S., Schmidt, K., Spracklin, D.K., Szewc, M., Troutman, M., Tseng, E., Tu, M., Van Deusen, J.W., Venkatakrishnan, K., Walens, G., Wang, E.Q., Wong, D., Yasgar, A.S., Zhang, C., 2005. The impact of P-glycoprotein on the disposition of drugs targeted for indications of the central nervous system: evaluation using the MDR1A/1B knockout mouse model. Drug Metab. Dispos. 33, 165-174.

Ebinger, M., Uhr, M., 2006. ABC drug transporter at the blood-brain barrier: effects on drug metabolism and drug response. Eur. Arch. Psychiatry Clin. Neurosci. 256, 294-298.

Ehret, M.J., Levin, G.M., Narasimhan, M., Rathinavelu, A., 2007. Venlafaxine induces Pglycoprotein in human Caco-2 cells. Hum. Psychopharmacol. 22, 49-53.

Ejsing, T.B., Morling, N., Linnet, K., 2007. A review on the relation between the brain-serum concentration ratio of drugs and the influence of P-glycoprotein. Drug Metabol. Drug Interact. 22, 113-129.

Endres, C. J., Hsiao, P., Chung, F. S., Unadkat, J. D., 2006. The role of transporters in drug interactions. Eur. J. Pharm. Sci. 27, 501-517.

Fudio, S., Borobia, A.M., Piñana, E., Ramírez, E., Tabarés, B., Guerra, P., Carcas, A., Frías, J., 2010. Evaluation of the influence of sex and CYP2C19 and CYP2D6 polymorphisms in the disposition of citalopram. Eur. J. Pharmacol. 626, 200-204.

Garrigues, A., Loiseau, N., Delaforge, M., Ferté, J., Garrigos, M., André, F., Orlowski, S., 2002. Characterization of two pharmacophores on the multidrug transporter P-glycoprotein. Mol. Pharmacol. 62, 1288-1298.

Gutmann, H., Poller, B., Buter, K.B., Pfrunder, A., Schaffner, W., Drewe, J., 2006. Hypericum perforatum: which constituents may induce intestinal MDR1 and CYP3A4 mRNA expression? Planta Med. 72, 685-690. 
Hoffmeyer, S., Burk, O., von Richter, O., Arnold, H.P., Brockmoller, J., Johne, A., Cascorbi, I., Gerloff, T., Roots, I., Eichelbaum, M., Brinkmann, U., 2000. Functional polymorphisms of the human multidrug-resistance gene: multiple sequence variations and correlation of one allele with P-glycoprotein expression and activity in vivo. Proc. Natl. Acad. Sci. U S A. 97, 3473-3478.

Hyttel, J., Bogeso, K.P., Perregaard, J., Sanchez, C., 1992. The pharmacological effect of citalopram resides in the (S)-(+)-enantiomer. J. Neural Transm. Gen. Sect. 88, 157-160.

Karlsson, L., Hiemke, C., Carlsson, B., Josefsson, M., Ahlner, J., Bengtsson, F., Schmitt, U., Kugelberg, F.C., 2011. Effects on enantiomeric drug disposition and open-field behavior after chronic treatment with venlafaxine in the P-glycoprotein knockout mice model.

Psychopharmacology (Berl). 215, 367-377.

Karlsson, L., Schmitt, U., Josefsson, M., Carlsson, B., Ahlner, J., Bengtsson, F., Kugelberg, F.C., Hiemke, C., 2010. Blood-brain barrier penetration of the enantiomers of venlafaxine and its metabolites in mice lacking P-glycoprotein. Eur. Neuropsychopharmacol. 20, 632-640.

Kim, R.B., Leake, B.F., Choo, E.F., Dresser, G.K., Kubba, S.V., Schwarz, U.I., Taylor, A., Xie, H.G., McKinsey, J., Zhou, S., Lan, L.B., Schuetz, J.D., Schuetz, E.G., Wilkinson, G.R., 2001. Identification of functionally variant MDR1 alleles among European Americans and African Americans. Clin. Pharmacol Ther. 70, 189-199.

Kirschbaum, K.M., Henken, S., Hiemke, C., Schmitt, U., 2008. Pharmacodynamic consequences of P-glycoprotein-dependent pharmacokinetics of risperidone and haloperidol in mice. Behav. Brain Res. 188, 298-303.

Kosel, M., Amey, M., Aubert, A.C., Baumann, P., 2001. In vitro metabolism of citalopram by monoamine oxidase B in human blood. Eur. Neuropsychopharmacol. 11, 75-78.

Kugelberg, F.C., Apelqvist, G., Carlsson, B., Ahlner, J., Bengtsson, F., 2001. In vivo steadystate pharmacokinetic outcome following clinical and toxic doses of racemic citalopram to rats. Br. J. Pharmacol. 132, 1683-1690.

Kugelberg, F.C., Carlsson, B., Ahlner, J., Bengtsson, F., 2003. Stereoselective single-dose kinetics of citalopram and its metabolites in rats. Chirality. 15, 622-629.

Lepola, U., Wade, A., Andersen, H.F., 2004. Do equivalent doses of escitalopram and citalopram have similar efficacy? A pooled analysis of two positive placebo-controlled studies in major depressive disorder. Int. Clin. Psychopharmacol. 19, 149-155.

Linnet, K., Ejsing, T.B., 2008. A review on the impact of P-glycoprotein on the penetration of drugs into the brain. Focus on psychotropic drugs. Eur. Neuropsychopharmacol. 18, 157-169.

Loscher, W., Potschka, H., 2005. Role of drug efflux transporters in the brain for drug disposition and treatment of brain diseases. Prog. Neurobiol. 76, 22-76.

Mansari, M.E., Wiborg, O., Mnie-Filali, O., Benturquia, N., Sanchez, C., Haddjeri, N., 2007. Allosteric modulation of the effect of escitalopram, paroxetine and fluoxetine: in-vitro and invivo studies. Int. J. Neuropsychopharmacol. 10, 31-40. 
Mayer, U., Wagenaar, E., Dorobek, B., Beijnen, J.H., Borst, P., Schinkel, A.H., 1997. Full blockade of intestinal P-glycoprotein and extensive inhibition of blood-brain barrier Pglycoprotein by oral treatment of mice with PSC833. J. Clin. Invest. 100, 2430-2436.

Mnie-Filali, O., Faure, C., Mansari, M.E., Lambas-Senas, L., Berod, A., Zimmer, L., Sanchez, C., Haddjeri, N., 2007. R-citalopram prevents the neuronal adaptive changes induced by escitalopram. Neuroreport. 18, 1553-1556.

Montgomery, S.A., Loft, H., Sanchez, C., Reines, E.H., Papp, M., 2001. Escitalopram (Senantiomer of citalopram): clinical efficacy and onset of action predicted from a rat model. Pharmacol. Toxicol. 88, 282-286.

Mork, A., Kreilgaard, M., Sanchez, C., 2003. The R-enantiomer of citalopram counteracts escitalopram-induced increase in extracellular 5-HT in the frontal cortex of freely moving rats. Neuropharmacology. 45, 167-173.

Narang, V.S., Fraga, C., Kumar, N., Shen, J., Throm, S., Stewart, C.F., Waters, C.M., 2008. Dexamethasone increases expression and activity of multidrug resistance transporters at the rat blood-brain barrier. Am. J. Physiol. Cell Physiol. 295, C440-450.

O'Brien, F.E., Dinan, T.G., Griffin, B.T., Cryan, J.F., 2012. Interactions between antidepressants and P-glycoprotein at the blood-brain barrier: clinical significance of in vitro and in vivo findings. Br. J. Pharmacol. 165, 289-312.

Olesen, O.V., Linnet, K., 1999. Studies on the stereoselective metabolism of citalopram by human liver microsomes and cDNA-expressed cytochrome P450 enzymes. Pharmacology. 59, 298-309.

Owens, M.J., Knight, D.L., Nemeroff, C.B., 2001. Second-generation SSRIs: human monoamine transporter binding profile of escitalopram and R-fluoxetine. Biol. Psychiatry. 50, 345-350.

Perloff, M.D., von Moltke, L.L., Greenblatt, D.J., 2004. Ritonavir and dexamethasone induce expression of CYP3A and P-glycoprotein in rats. Xenobiotica. 34, 133-150.

Reis, M., Lundmark, J., Bengtsson, F., 2003. Therapeutic drug monitoring of racemic citalopram: a 5-year experience in Sweden, 1992-1997. Ther. Drug Monit. 25, 183-191.

Rochat, B., Amey, M., Baumann, P., 1995. Analysis of enantiomers of citalopram and its demethylated metabolites in plasma of depressive patients using chiral reverse-phase liquid chromatography. Ther. Drug Monit. 17, 273-279.

Rochat, B., Baumann, P., Audus, K.L., 1999. Transport mechanisms for the antidepressant citalopram in brain microvessel endothelium. Brain. Res. 831, 229-236.

Rochat, B., Kosel, M., Boss, G., Testa, B., Gillet, M., Baumann, P., 1998. Stereoselective biotransformation of the selective serotonin reuptake inhibitor citalopram and its demethylated metabolites by monoamine oxidases in human liver. Biochem. Pharmacol. 56, $15-23$. 
Sanchez, C., Bergqvist, P.B.F., Brennum, L.T., Gupta, S., Hogg, S., Larsen, A., Wiborg, O., 2003a. Escitalopram, the S-(+)-enantiomer of citalopram, is a selective serotonin reuptake inhibitor with potent effects in animal models predictive of antidepressant and anxiolytic activities. Psychopharmacology (Berl). 167, 353-362.

Sanchez, C., Bogeso, K.P., Ebert, B., Reines, E.H., Braestrup, C., 2004. Escitalopram versus citalopram: the surprising role of the R-enantiomer. Psychopharmacology (Berl). 174, 163 176.

Sanchez, C., Gruca, P., Bien, E., Papp, M., 2003b. R-citalopram counteracts the effect of escitalopram in a rat conditioned fear stress model of anxiety. Pharmacol. Biochem. Behav. 75, 903-907.

Sanchez, C., Gruca, P., Papp, M., 2003c. R-citalopram counteracts the antidepressant-like effect of escitalopram in a rat chronic mild stress model. Behav. Pharmacol. 14, 465-470.

Sanchez, C., Kreilgaard, M., 2004. R-citalopram inhibits functional and 5-HTP-evoked behavioural responses to the SSRI, escitalopram. Pharmacol. Biochem. Behav. 77, 391-398.

Thiebaut, F., Tsuruo, T., Hamada, H., Gottesman, M. M., Pastan, I., Willingham, M. C., 1987. Cellular localization of the multidrug-resistance gene product $\mathrm{P}$-glycoprotein in normal human tissues. Proc. Natl. Acad. Sci. U S A. 84, 7735-7738.

Thiebaut, F., Tsuruo, T., Hamada, H., Gottesman, M. M., Pastan, I., Willingham, M. C., 1989. Immunohistochemical localization in normal tissues of different epitopes in the multidrug transport protein P170: evidence for localization in brain capillaries and crossreactivity of one antibody with a muscle protein. J. Histochem. Cytochem. 37, 159-164.

Uhr, M., Grauer, M.T., 2003. abcb1ab P-glycoprotein is involved in the uptake of citalopram and trimipramine into the brain of mice. J. Psychiatr. Res. 37, 179-185.

Uhr, M., Grauer, M.T., Holsboer, F., 2003. Differential enhancement of antidepressant penetration into the brain in mice with abcblab (mdr1ab) P-glycoprotein gene disruption. Biol. Psychiatry. 54, 840-846.

Uhr, M., Grauer, M. T., Yassouridis, A., Ebinger, M., 2007. Blood-brain barrier penetration and pharmacokinetics of amitriptyline and its metabolites in p-glycoprotein (abcb1ab) knockout mice and controls. J. Psychiatr. Res. 41, 179-188.

Uhr, M., Steckler, T., Yassouridis, A., Holsboer, F., 2000. Penetration of amitriptyline, but not of fluoxetine, into brain is enhanced in mice with blood-brain barrier deficiency due to mdr1a P-glycoprotein gene disruption. Neuropsychopharmacology. 22, 380-387.

Uhr, M., Tontsch, A., Namendorf, C., Ripke, S., Lucae, S., Ising, M., Dose, T., Ebinger, M., Rosenhagen, M., Kohli, M., Kloiber, S., Salyakina, D., Bettecken, T., Specht, M., Putz, B., Binder, E.B., Muller-Myhsok, B., Holsboer, F., 2008. Polymorphisms in the drug transporter gene ABCB1 predict antidepressant treatment response in depression. Neuron. 57, 203-209. 
Wade, A., Michael Lemming, O., Bang Hedegaard, K., 2002. Escitalopram 10 mg/day is effective and well tolerated in a placebo-controlled study in depression in primary care. Int. Clin. Psychopharmacol. 17, 95-102.

Wang, J.S., Ruan, Y., Taylor, R.M., Donovan, J.L., Markowitz, J.S., DeVane, C.L., 2004. The brain entry of risperidone and 9-hydroxyrisperidone is greatly limited by P-glycoprotein. Int. J. Neuropsychopharmacol. 7, 415-419.

Wikell, C., Apelqvist, G., Carlsson, B., Hjorth, S., Bergqvist, P.B.F., Kugelberg, F.C., Ahlner, J., Bengtsson, F., 1999. Pharmacokinetic and pharmacodynamic responses to chronic administration of the selective serotonin reuptake inhibitor citalopram in rats. Clin. Neuropharmacol. 22, 327-336.

Yin, O.Q., Wing, Y.K., Cheung, Y., Wang, Z.J., Lam, S.L., Chiu, H.F., Chow, M.S., 2006. Phenotype-genotype relationship and clinical effects of citalopram in Chinese patients. J.

Clin. Psychopharmacol. 26, 367-372. 


\section{Figure legends}

Figure 1. Serum and brain S-citalopram concentrations in $a b c b l a b(-/-)$ and $a b c b l a b(+/+)$ mice after acute ( $1 \mathrm{~h}$ and $3 \mathrm{~h}$ post dosing) and chronic (10 days; $1 \mathrm{~h}$ after the last injection) treatment with citalopram (A and C) or escitalopram (B and D). Values are means \pm SEM $(n=5) * * p<0.01, * * * p<0.001$

Figure 2. Brain/serum concentration ratios of S-citalopram and S-dm-citalopram in $a b c b l a b(-/-)$ and $a b c b l a b(+/+)$ mice after acute $(1 \mathrm{~h}$ and $3 \mathrm{~h}$ post dosing) and chronic (10 days; $1 \mathrm{~h}$ after the last injection) treatment with citalopram (A and C) or escitalopram (B and D). Values are means $\pm \operatorname{SEM}(n=5) * * * p<0.001$

Figure 3. Serum $S / R$ concentration ratios $(A$ and $B)$ and brain $S / R$ concentration ratios $(C$ and D) of citalopram, demethylcitalopram (dm-citalopram) and didemethylcitalopram (ddmcitalopram) in $a b c b l a b(-/-)$ and $a b c b l a b(+/+)$ mice after acute ( $1 \mathrm{~h}$ post dosing) and chronic (10 days; $1 \mathrm{~h}$ after the last injection) treatment with racemic citalopram. Values are means \pm $\operatorname{SEM}(n=5) * p<0.05, * * p<0.01, * * * p<0.001$ 
Figure 1.

A

Citalopram 10mg/kg

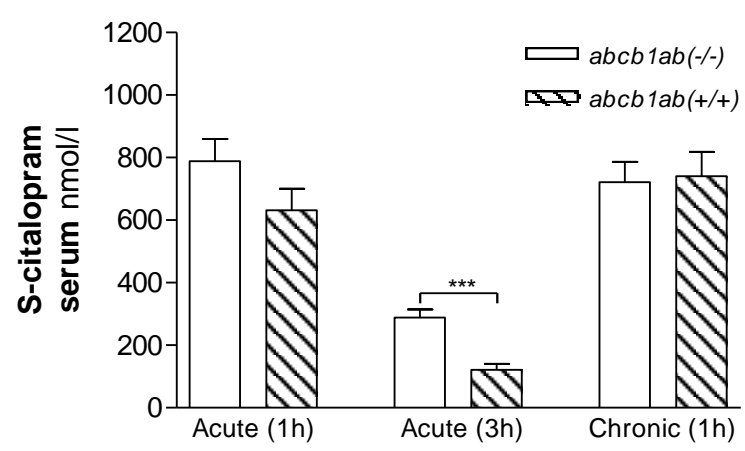

C

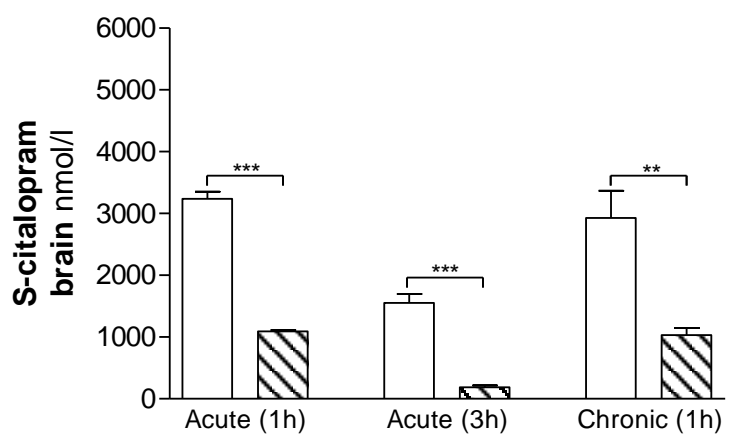

B Escitalopram $5 \mathrm{mg} / \mathrm{kg}$

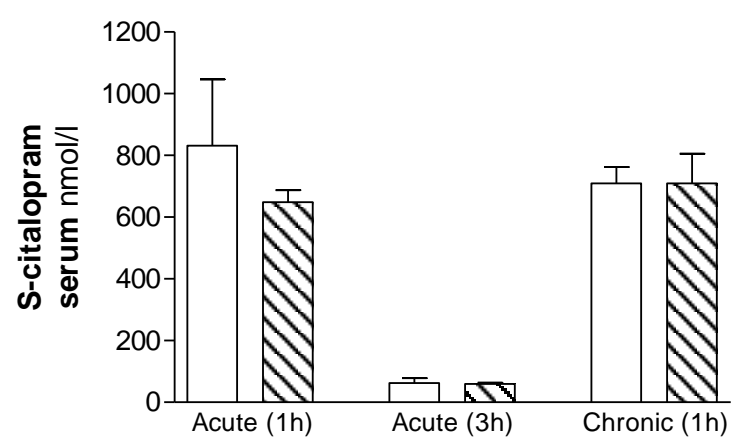

D

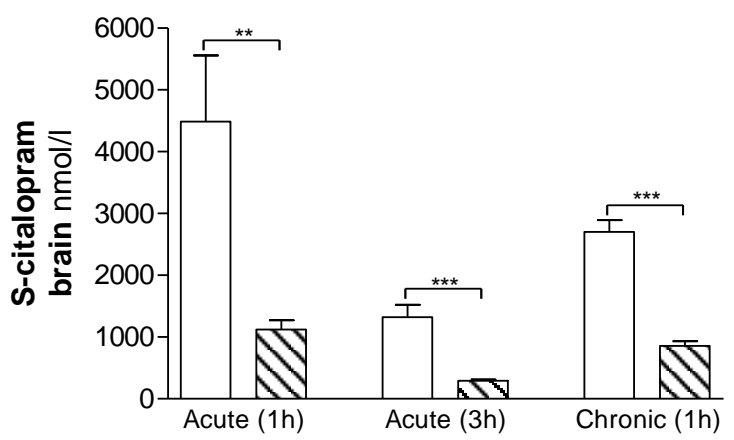


Figure 2.

A

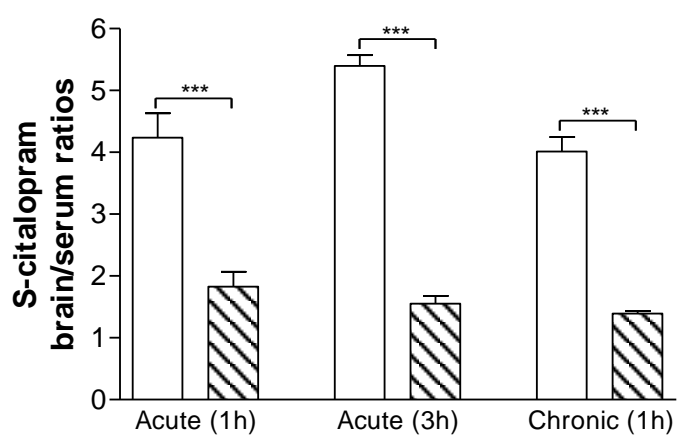

C

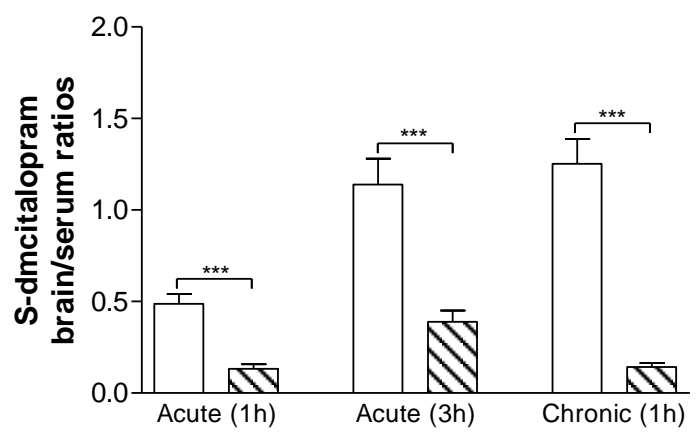

B Escitalopram $5 \mathrm{mg} / \mathrm{kg}$

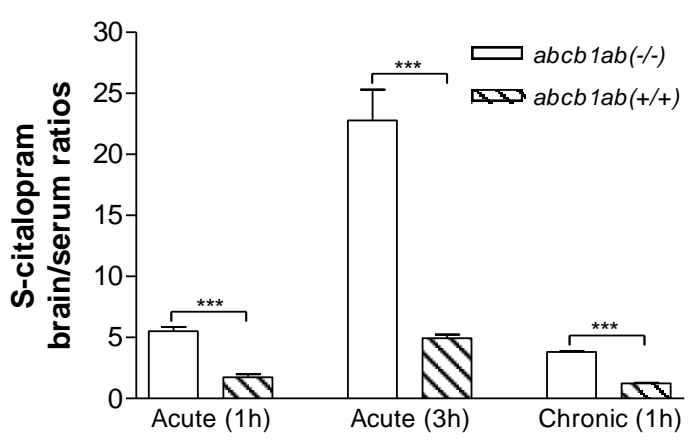

D

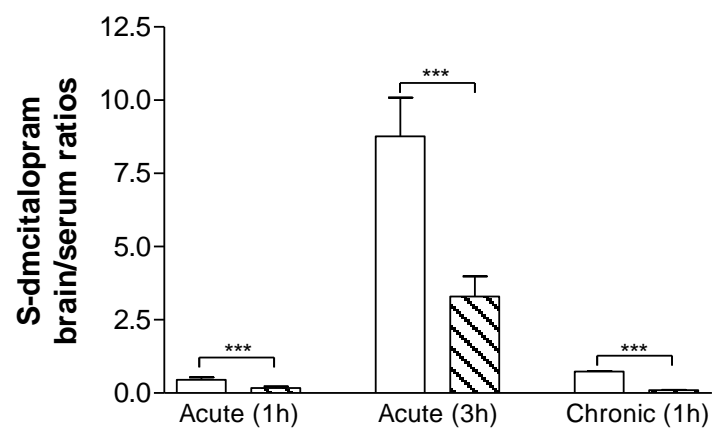


Figure 3.
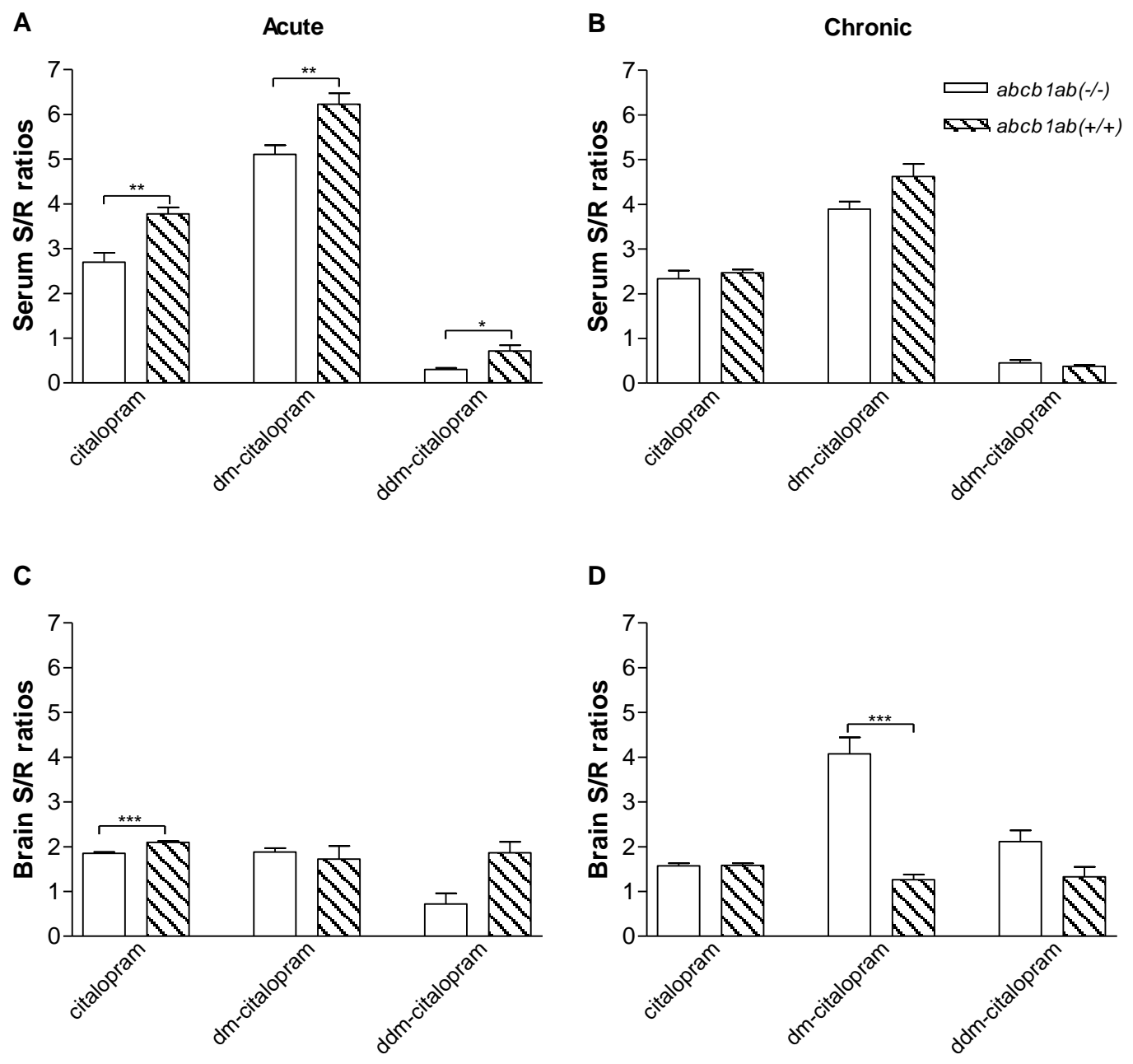
Table 1. Concentrations (S- and R-enantiomer) of citalopram in $a b c b l a b(-/-)$ and $a b c b l a b(+/+)$ mice after acute (1-6 h) and chronic (10 days) treatment with $10 \mathrm{mg} / \mathrm{kg}$ of citalopram or $5 \mathrm{mg} / \mathrm{kg}$ of escitalopram. For the citalopram experiment, enantiomeric ratios (S/R) of citalopram are also shown.

\begin{tabular}{|c|c|c|c|c|c|c|}
\hline \multirow[b]{3}{*}{ Treatment } & & & \multicolumn{2}{|c|}{ Serum } & \multicolumn{2}{|c|}{ Brain } \\
\hline & & & $a b c b l a b(-/-)$ & $a b c b l a b(+/+)$ & $a b c b l a b(-/-)$ & $a b c b l a b(+/+)$ \\
\hline & & & mean \pm SEM & mean \pm SEM & mean \pm SEM & mean \pm SEM \\
\hline \multirow[t]{11}{*}{ Citalopram 10 mg/kg } & $1 \mathrm{~h}$ & S-enantiomer & $788 \pm 72$ & $632 \pm 68$ & $3236 \pm 118^{* * *}$ & $1092 \pm 22$ \\
\hline & & R-enantiomer & $302 \pm 41^{*}$ & $166 \pm 15$ & $1750 \pm 85^{* * *}$ & $520 \pm 12$ \\
\hline & & $\mathrm{S} / \mathrm{R}$ ratio & $2.70^{* *}$ & 3.78 & $1.85^{* * *}$ & 2.10 \\
\hline & $3 \mathrm{~h}$ & S-enantiomer & $288 \pm 26$ & $121 \pm 20$ & $1554 \pm 146$ & $187 \pm 30$ \\
\hline & & R-enantiomer & $54.8 \pm 5.0$ & $25.3 \pm 2.5$ & $387 \pm 47$ & $80.0(\mathrm{n}=1)$ \\
\hline & & $\mathrm{S} / \mathrm{R}$ ratio & 5.27 & 5.18 & 4.07 & $n c$ \\
\hline & $6 \mathrm{~h}$ & S-enantiomer & $27.1 \pm 2.3$ & nd & $197 \pm 14$ & $79.0(\mathrm{n}=1)$ \\
\hline & & R-enantiomer & $n d$ & nd & nd & nd \\
\hline & 10 days & S-enantiomer & $722 \pm 64$ & $740 \pm 78$ & $2926 \pm 440^{* *}$ & $1032 \pm 115$ \\
\hline & & R-enantiomer & $310 \pm 22$ & $301 \pm 34$ & $1853 \pm 229^{* * *}$ & $654 \pm 76$ \\
\hline & & $\mathrm{S} / \mathrm{R}$ ratio & 2.34 & 2.47 & 1.57 & 1.58 \\
\hline \multirow[t]{4}{*}{ Escitalopram $5 \mathrm{mg} / \mathrm{kg}$} & $1 \mathrm{~h}$ & S-enantiomer & $832 \pm 215$ & $648 \pm 40$ & $4489 \pm 1066^{* *}$ & $1121 \pm 150$ \\
\hline & $3 \mathrm{~h}$ & S-enantiomer & $62.9 \pm 15$ & $59.3 \pm 4.6$ & $1325 \pm 197$ & $290 \pm 22$ \\
\hline & $6 \mathrm{~h}$ & S-enantiomer & $20.4(n=1)$ & $n d$ & $270 \pm 44$ & nd \\
\hline & 10 days & S-enantiomer & $709 \pm 53$ & $710 \pm 96$ & $2702 \pm 190^{* * *}$ & $857 \pm 77$ \\
\hline
\end{tabular}

Concentrations in $\mathrm{nmol} / \mathrm{l}$. Values are means $\pm \operatorname{SEM}(n=5) * * * \mathrm{p}<0.001, * * \mathrm{p}<0.01, * \mathrm{p}<0.05$ significant differences between $a b c b 1 a b(-/-)$ and $a b c b 1 a b(+/+) . n d:$ not detected, $n c:$ not calculated 
Table 2. S-enantiomer concentrations of demethylcitalopram (S-dm-citalopram) and didemethylcitalopram (S-ddm-citalopram) in abcblab (-/-) and $a b c b l a b(+/+)$ mice after acute (1-6 h) and chronic (10 days) treatment with $10 \mathrm{mg} / \mathrm{kg}$ of citalopram or $5 \mathrm{mg} / \mathrm{kg}$ of escitalopram.

\begin{tabular}{|c|c|c|c|c|c|}
\hline \multirow[b]{3}{*}{ Treatment } & \multirow[b]{3}{*}{ Time } & \multicolumn{2}{|c|}{ Serum } & \multicolumn{2}{|c|}{ Brain } \\
\hline & & $a b c b l a b(-/-)$ & $a b c b 1 a b(+/+)$ & $a b c b l a b(-/-)$ & $a b c b l a b(+/+)$ \\
\hline & & mean \pm SEM & mean \pm SEM & mean \pm SEM & mean \pm SEM \\
\hline \multicolumn{6}{|l|}{ Citalopram 10 mg/kg } \\
\hline \multirow[t]{4}{*}{ S-dm-citalopram } & $1 \mathrm{~h}$ & $530 \pm 60$ & $771 \pm 130$ & $248 \pm 15^{* * *}$ & $90.6 \pm 3.7$ \\
\hline & $3 \mathrm{~h}$ & $807 \pm 86^{*}$ & $542 \pm 74$ & $890 \pm 82^{* * *}$ & $194 \pm 15$ \\
\hline & $6 \mathrm{~h}$ & $151 \pm 27$ & $102 \pm 15$ & $1508 \pm 25^{* * * *}$ & $274 \pm 29$ \\
\hline & 10 days & $503 \pm 60$ & $526 \pm 37$ & $628 \pm 72^{* * *}$ & $48.3 \pm 3.4$ \\
\hline \multirow[t]{4}{*}{ S-ddm-citalopram } & $1 \mathrm{~h}$ & $37.3 \pm 3.1^{* * *}$ & $84.2 \pm 10$ & $24.6 \pm 9.1$ & $28.7(n=2)$ \\
\hline & $3 \mathrm{~h}$ & $223 \pm 19^{* *}$ & $358 \pm 32$ & $56.5 \pm 7.4^{* * * *}$ & $16.0 \pm 2.9$ \\
\hline & $6 \mathrm{~h}$ & $175 \pm 32$ & $179 \pm 13$ & $179 \pm 11^{* * *}$ & $39.3 \pm 5.9$ \\
\hline & 10 days & $62.3 \pm 3.5$ & $53.7 \pm 2.2$ & $191 \pm 29^{* * *}$ & $11.3 \pm 4.8$ \\
\hline \multicolumn{6}{|l|}{ Escitalopram $5 \mathrm{mg} / \mathrm{kg}$} \\
\hline \multirow[t]{4}{*}{ S-dm-citalopram } & $1 \mathrm{~h}$ & $2461 \pm 570$ & $1915 \pm 149$ & $966 \pm 59^{* * * *}$ & $305 \pm 62$ \\
\hline & $3 \mathrm{~h}$ & $537 \pm 93$ & $395 \pm 62$ & $4311 \pm 318^{* * *}$ & $1131 \pm 86$ \\
\hline & $6 \mathrm{~h}$ & $218 \pm 14^{* *}$ & $126 \pm 13$ & $2704 \pm 317^{* * * *}$ & $663 \pm 84$ \\
\hline & 10 days & $903 \pm 56$ & $1036 \pm 114$ & $662 \pm 35^{* * *}$ & $104 \pm 6.9$ \\
\hline \multirow[t]{4}{*}{ S-ddm-citalopram } & $1 \mathrm{~h}$ & $558 \pm 62$ & $517 \pm 52$ & $48.3 \pm 8.2$ & $18.3(\mathrm{n}=2)$ \\
\hline & $3 \mathrm{~h}$ & $530 \pm 30^{* *}$ & $353 \pm 39$ & $759 \pm 89^{* * *}$ & $146 \pm 17$ \\
\hline & $6 \mathrm{~h}$ & $293 \pm 26^{* *}$ & $187 \pm 17$ & $572 \pm 67^{* * *}$ & $90.4 \pm 9.4$ \\
\hline & 10 days & $217 \pm 12$ & $246 \pm 7.8$ & $243 \pm 11^{* * *}$ & $24.6 \pm 2.9$ \\
\hline
\end{tabular}

Concentrations in nmol/l. Values are means $\pm \operatorname{SEM}(n=5) * * * \mathrm{p}<0.001, * * \mathrm{p}<0.01,{ }^{*} \mathrm{p}<0.05$ significant differences between $a b c b l a b(-/-)$ and $a b c b l a b(+/+)$. 